\title{
A Sociopragmatic Analysis of Women and Gender Roles in John Galsworthy's Forsyte Saga and Naguib Mahfouz's Cairo Trilogy
}

\author{
Abdulfattah $\mathrm{Omar}^{1,2} \&$ Musa Ahmed Musa Alhassan ${ }^{1}$ \\ ${ }^{1}$ Department of English, College of Science \& Humanities, Prince Sattam Bin Abdulaziz University, Saudi \\ Arabia \\ ${ }^{2}$ Department of English, Faculty of Arts, Port Said University, Egypt \\ Correspondence: Abdulfattah Omar, Department of English, College of Science \& Humanities, Prince Sattam \\ Bin Abdulaziz University, Al-Kharj, Riyadh, 11942, Saudi Arabia. E-mail: a.abdelfattah@psau.edu.sa
}

Received: December 26, 2019 Accepted: January 28, 2020 Online Published: February 13, 2020

doi:10.5539/ijel.v10n2p284 URL: https://doi.org/10.5539/ijel.v10n2p284

\begin{abstract}
This study is concerned with investigating the treatment of women and gender roles in Glasworthy's Forsyte Saga and Naguib Mahfouz's Cairo Trilogy from a sociopragmatic perspective. The texts studied for this paper have not been evaluated to socio-pragmatic analysis that reflects the little application of this approach to literary works. As thus, the goal of this paper is to advance sociopragmatic analysis to these novels - there is salience from the style, narrative techniques, and language utilized by both writers in their books, which indeed points to pragmatic undercurrents that must be explored. The results indicate that social and political aspects are key elements for understanding women and gender issues in the selected texts. The integration of these contextual elements revealed how the two authors manipulated literary discourse to reflect on the power relations and struggles between men and women of their age. It can be claimed that sociopragmatic approaches provide opportunities for understanding the hidden layers within the selected texts in terms of social practices and interactions among characters. It is finally suggested that sociopragmatic approaches should be integrated into literary studies for a better and deeper understanding of literary discourse in general and crosscultural issues in particular.
\end{abstract}

Keywords: Cairo Trilogy, Forsyte Saga, gender roles, literary discourse, sociopragmatics

\section{Introduction}

This study aims to assess the authorial treatment of women and gender roles in one period of English and Egyptian prose fiction based on John Galsworthy's Forsyte Saga with focus on The Man of Property and Naguib Mahfouz's Cairo Trilogy with focus on Bain Al-Qasrain, translated into English as Palace Walk. Both novels are the first volumes within trilogies that aim to highlight the social, political, cultural, and artistic events of the country during World War 1 even though they were written at different times (Crow, 2000; El-Shall, 2006; Ghị̦̂ānī, 2012; Gorsky, 1992; Santesso \& McClung, 2017).

Galsworthy's (1922) Forsyte Saga gives one of the most complete and critical pictures that we have of English bourgeois society at the beginning of the 20th century. Here, the author deals with contemporary social problems through tracing the life of three generations of the Forsyte family from the eighties of the nineteenth century up to the twenties of the twentieth century. The Man of Property is the most outstanding volume within the family Saga. It is even described as the most popular and probably the best of the score of novels written by John Galsworthy (Frechet, 1982; Langbauer, 1999). In Cairo Trilogy, Mahfouz chronicles the British occupation of Egypt and Sudan, which was under the rule of Egypt at that time, in the wake of the British-ordered exile of the Egyptian revolutionary leader Saad Zaghloul, and numerous other members of the Wafd Party. Palace Walk is also the most outstanding volume within Cairo Trilogy. In spite of the political background of the narrative, much of the novel is devoted to the established traditions and customs of family life behind the walls of the house on the Palace Walk, one of the historic places in Cairo. The implication here is that the two texts are similar to each other in treating social and family life in all its details which is a good starting point to investigate how each of the two writers treated the concepts of women and gender roles in his novel. In the light of this argument, this study asks the following research questions. First, how is the representation of women and gender issues conducted in Galsworthy's Forsyte Saga and Mahfouz's Cairo Trilogy? Second, can feminist aspects in 
Galsworthy's Forsyte Saga and Mahfouz's Cairo Trilogy be interpreted within the sociopragmatic framework?

\section{Literature Review}

Sociopragmatics as an approach to the study language and discourse was first formulated by the English linguist Geoffrey Leech (1983) where he distinguished three areas of pragmatics. These are general pragmatics, sociopragmatics, and pragmalinguistics. He referred to sociopragmatics as that subfield or part of pragmatics that is more concerned with specific local conditions on language use. Leech (1983) theoretically proposes sociopragmatics to concern how discourse relates to "specific" "local" "conditions" with its pragmatic mode. Culpeper (2011), however, comments that Leech's definition is not satisfactory. He indicates that there is an overlap between the two terms of pragmatics and sociopragmatics since pragmatics involves a general cognitive, social, and cultural perspective on linguistic phenomena in relation to their usage in forms of behaviour. In other words, Leech's definition reflects that both pragmatics and sociopragmatics are concerned with social contextualization of language use with no dividing lines between the two concepts. He adds that from Leech's perspective, all phenomena encompassed by pragmatics are social making no difference between pragmatics and sociopragmatics. A way out of the problem, Culpeper $(2011$, p. 1) suggests that sociopragmatics can be defined as that part of pragmatics that "concerns itself with any aspect of the social context that is specific to the pragmatic meanings of particular language use". Likewise, Lutzky (2012) suggests that sociopragmatics considers the social milieus that underwrite how our functional language form manifests. Nonetheless, Leech's construct finds interrelation with language and linguistics philosophy; more specifically, it explores the representation of issues such as gender and racism in both written and spoken discourse.

The sociopragmatic approach can be traced back to Pragmatism, an American tradition founded in the late nineteenth century by a group of Harvard academics named the 'Metaphysical Club'. This was a conversational philosophical circle consisting of the pragmatists William James and Charles Sanders Peirce, plus future Supreme Court Judge Oliver Wendell Holmes Jr. Their discussions advanced a dissonant conception of foundationalism to a moderate scale; contrastingly to its radical schema in Europe, American pragmatism sought to reduce ontological questions to practical constructs. In this tradition, the pragmatism model asserts that all words and thoughts have scientific utility; in other words, these expressions have logical, not interpretive modalities.

Over the recent years, sociopragmatic approaches have been widely used in the analysis of different discourse genres especially political discourse, media discourse, politeness strategies and the perception/ production of speech acts in order to investigate the cultural, historical and social construction of the relations between world, things and individuals (Al-Issa, 2003; Beeching \& Woodfield, 2015; Khosrowpour, 2002; Lutzky, 2012; Riley, 2007). In literature, however, sociopragmatic approaches have not been widely applied in spite of potentials they can give in comparative studies and in terms of interpreting cross-cultural issues including feminism and gender roles. This study addresses this gap in the literature through the discussion of gender paradigms in the Great War period in John Galsworthy's Forsyte Saga and Mahfouz's Cairo Trilogy reflecting on the utility of sociopragmatic analysis in reconstructing meanings expressed by the participants.

\section{Methodology}

This study attempts to investigate the representation of women issues and gender roles in Galsworthy and Mahfouz's books through sociopragmatic analysis to connect how language is constructed in their novels to convey social and political meanings. The rationale is that sociopragmatic analysis primarily can interconnect with other literary and linguistic concepts - specifically with pragmatics and feminism to identify the social, cognitive, and cultural perspectives conveyed in the respective novels. Indeed, sociopragmatics adherents had repertoires of their arguments in different discourse genres including media and political discourse, but no major emergence of sociopragmatic theory to literary thought is apparent. Nonetheless, this paper will advance how sociopragmatic approaches can be usefully used in rereading John Galsworthy's The Man of Property and Naguib Mahfouz's Palace Walk.

In this study, Speech Acts Theory will be first interrelated to Galsworthy and Mahfouz's narratives. Leech had excoriated Karl Popper's idea of the three actual compound worlds, to underline how collective perceptions form our reality. Yet the real beginning of pragmatic approaches as a systematic and disciplined study of meaning dates back to 1962 with the publication of John Austin's How To Do Things With Words. In this book, Austin pointed out that language should be studied within a pragmatic framework. That is, language should be investigated in terms of the speaker and the context of speech. Austin (1962) argued that discourse should be seen as a linguistic event in which both the speaker and listener are involved. Austin's pragmatic approach to the study of discourse marks one of the pioneering and earliest attempts to study the relationship between form and 
function. Austin's Speech Acts theory has long had an influential effect on the studies of discourse since it is concerned with what people are doing when they produce their utterances. Austin suggests that ordinary language embodies all of the practical distinctions that will prove useful in human life. In this way, he paid special attention to the analysis of the relationship between utterances and performances. He argues that there are five categories of performatives. They are Verdictives, Exercitives, Commissives, Behabitives, and Expositives. Austin also remarks that any utterance has three forces, locutionary force, illocutionary force, and a perlocutionary force. A locutionary force is the basic act of reference; it is the meaningful linguistic expression. An illocutionary force is the communicative force of the utterance. A perlocutionary force is the influence of the utterance upon the recipient. A different approach to distinguishing types of speech acts can be made on the basis of structure. Whenever there is a direct relationship between a structure and a function, we have a direct speech act. Whenever there is an indirect relationship between a structure and a function, we have an indirect speech act. Thus, a declarative used to make a statement is a direct speech act, but a declarative used to make a request is an indirect speech act.

Searle (1969) observed that Austin's concept of speech acts is inappropriate and cannot be applied to all cases. He did not agree with Austin in dividing utterances only into performatives and constatives: "I do not claim this is the only way to divide them" $(1969$, p. 25$)$. He indicated that Austin's theory is philosophical rather than linguistic. In this regard, he devised new rules for speech act classification that are different from those of Austin. Searle's concepts of speech acts are manifested in Expression and Meaning. In this book, Searle (1979) identifies five categories of speech acts. They are assertives, directives, expressives, commissives, and declaratives: "we tell people how things are (Assertives), we try to get them to do things (Directives), we commit ourselves to doing things (Commissives), we express our feelings and attitudes (Expressives), and we bring about changes in the world through our utterances (Declarations)" (1979, p. viii). Ryckebusch and Marcos (2004) provide these brief definitions of Searle's five categories: "assertives are descriptions of 'the state of the world'; directives are utterances aimed at getting one's partner to do something; expressives state the speaker's attitude about 'the state of the world', i.e., his/her psychological state; commisives commit the speaker to performing some future action; declaratives are propositions that modify the 'state of the world' by the sheer fact that they are uttered by a person of appropriate status" (2004, p. 884). Searle's works and Austin's earlier book laid the foundations of the Speech Acts Theory, an unprecedented step in the development of pragmatics.

In The Man of Property, there too is a practical overtone that depicts the characters, story and locational settings. If Leech's postulation that our existence is interpreted from observational commonality, then in Galsworthy's book dreary conventionalism plateaus the story. This is since The Man of Property is mechanically painted from its authorial voice; Galsworthy renders pragmatism in it to limit anomalies from individual discourse. Furthermore, an imperative thread of the whole novel is the little transcendence in statements and imagery; its social mobility plotline is rescinded by the end of the book. In this way, sociopragmatism is symbolically intertwined with Galsworthy's articulation of the late-Victorian milieu. Indeed, the era's social politics are interpreted in The Man of Property's ordinary narrative voice, with parallels in it muted, plain depictions.

Likewise, Naguib Mahfouz's Palace Walk signifies how the authorial voice can delineate constructs of reality to pragmatic interpretations. Throughout the novel, there is an approach by Mahfouz to retain narrative direction to a still form. This stylistic is emblematized in the Al-Jawad family's socio-psychological problems-their disconnecting relationships do not progress. He undertakes a social realistic approach in underpinning the central arguments in his book to its linguistic frame. In the Palace Walk, the interconnections between the language and downbeat ambiance strikes the descriptive, not conceptual objective that Mahfouz advances starkly. Indeed, the dramas in the novel find foundational drive from language direction. An example is of the plot concerning the stationing of British soldiers in Cairo. Contrasting to any revolutionary optimism from anticolonial aspirations concurrent in Egypt, Mahfouz assumes an almost despairing approach to the imperial defeat. Certainly, in this way, an existential or graceful painting of Cairo during the Great War is not apparent in Palace Walk, which reaffirms my assertion that Mahfouz's works can be read from a sociopragmatic perspective.

This paper thus considers how the sociopragmatic approach can be utilized in both Palace Walk and The Man of Property to discuss gender paradigms in the Great War period. Both Mahfouz and Galsworthy apply rational and clear political arguments to the questions of women's status that temporally their plots forward. For each, the structural rights of women have logical salience, but in their novels, there is no impetus on how socio-politics determine cognition to the women characters. This is meant that individual psychologies are not explored with significance. It is imperative to note that rendering women characters with psychoanalytical essentialism is not conversely plausible. For example, in regard for the sexualities of women characters, whether of central or peripheral positioning in the novels. In both books, the writers objectify women to denote their social 
commentaries on the respective repressive gender modes in Egypt and England. Nonetheless, there is an underscoring connection between women in Palace Walk and The Man of Property, that ascends over socioeconomic mantles. This is such that all the characters in this way concerned symbolically perform as an instrument for points of authorial ideology.

Nevertheless, it can seem problematic to crystallize the depictions of women to social statements. Writers then may sacrifice the vital connotations fostered in gendering stories, thus reiterating hegemonic metanarratives. For instance, the two books do not particularize a personal-is-political discourse in their accounts of women figures - such themes are to an extent absent owing to temporal frames. Primarily these characters are obscured in fatalistic constrictions that determine women's social locations to be the nexus to their metaphysical, social, political and psychological states. To expound, Galsworthy illustrates the pervading attitudes on sexual violence through an interplay with the character Irene's rape ordeal plotline. The overriding conception Galsworthy contends is social realism by undercutting psychological agency to socio-political problems. In another regard, Mahfouz premises his critique on Egypt's gender constructs by marking women characters to their conformity or dissonance to the country's societal model. One may posit that the novel's timeframe subjects Mahfouz's analytical scope. I understand this implication as a pragmatic stylistic, rather than an archaic default.

\section{Analysis}

In his portrayal of characters and events, Galsworthy underpins his observations conceptually in social objectivity. His medium of drawing an overall picture of the English society is the Forsyte family. The characters in Galsworthy's Saga speak to socially convey. All figures in this book are determined by the morals of Victorian England, the hypocrisy and conventions of society, and the marriage codes and laws play a significant role in shaping one's life. And due to these factors, people in The Man of Property are not happy. For example, the unhappy marriage of Soames and Irene with its negative implications is not only is deeply rooted in environmental, cultural, religious, social, and political factors: "The Forsytes with their ethics, morals, and principles are presented as unnatural, contradicting human nature and life, and thus doomed to destruction" (Hatif \& Hatif, 2012, p. 843), but also operate as social commentary about them.

In The Man of Property, there is no hope for any social reform. Edwards (2011, p. 201) maintains that the novel was published at a time when reform of the Victorian divorce laws was an increasingly topical issue. According to Kohlke and Gutleben $(2011$, p. 6), women were deprived of many of her rights, including divorce. They had to prove adultery in order to obtain divorce. Under these laws, Soames and Irene lived in permanent limbo. Linda Strahan argues that "Irene's unhappy marriage to Soames Forsyte has become a metaphor for the plight of women in nineteenth-century England before the passage of the Woman's Property Act (1881) and the agitation for further reforms". The Man of Property, which is set in the $1880 \mathrm{~s}$, depicts a nation, represented through London that rejects the Victorian ideals and traditions and tries to escape late Victorian London's horrors and darkness (Hubble, 2011). In the Saga, Galsworthy questions the British social order with its Victorian laws and conventions that impose numerous and harsh restrictions on one's life. Although Galsworthy is concerned with representing a real phenomenon of the late 19th century London society, there is, however, a tone of sadness that dominates the events of the story. Irene is beautiful but she is a passive actor. She is led from one act to another merely by the retaining of gender norms, without any experimental streams following her narrative. It is fate that determines her sad fate. This reflects a sort of pessimistic reality that is a characteristic feature of the novel and the saga. In his book The Outline of Literature, John Drinkwater (Drinkwater, 1923) argues that the Forsyte Saga reflects Galsworthy's mood of pessimism. In The English and American Estimates of Galsworthy as a Novelist, Elizabeth (Watson, 1973, p. 39) argued that The Saga dwells on the misfortunes of man where Galsworthy illustrates society's crudity and dullness. As such, he is extending a social 'local' crystallized in realism to appraise Victorian ideals.

Similarly, Naguib Mahfouz intended his trilogy to be social criticism. In Palace Walk, Mahfouz treats social, political, and religious themes against the background of early twentieth-century Egypt. Mahfouz portrays the conditions of the poor, oppression of the woman, conflict between generations, rapid rejection of age-old social norms, the inefficiency of bureaucracy, the growing influence of Western culture, and renunciation of religion among the urban middle class. In this, the novel can be located in the domain of social realism since it is greatly concerned with the relationship between individuals and society. In The Arab World: Society, Culture, and State, Barakat (1993, p. 210) argues that the novels of Naguib Mahfouz portray Egyptian life and society more comprehensively and accurately than the works of all the social scientists put together.

Mahfouz portrays the social and political life and illnesses of the age objectively and realistically. He presents himself as an objective observer, similar to a scientist taking note of what he sees. Mahfouz's vehicle for his 
examination of the Cairo society during that period is the family of Al-Sayyid Ahmad Abd Al-Jawad, a middle-class merchant who imposes upon his family — his wife Amina, his three sons and his two daughters-a strict religious regime and directs his behavior according to his desires and lusts. In spite of the father's tyrannical behavior towards his wife and children, they all obey him out of love, admiration, and respect. Although Mahfouz considered objectivity in the discussion of his different themes, a fairly deep-rooted social reality is often obvious throughout the text. People in Palace Walk lead lives that are regressive, which they cannot escape. The characters behave under the laws of science. Instinct and inherited traits drive their actions more than individual cognition. The characters are chained to the logical trajectories of their society, which makes apparent Mahfouz's social realistic framework.

The realistic tone that is felt at every part of the action is foregrounded by the feeling of national humiliation due to the British occupation of Egypt. Once Al-Sayyid Ahmad and his eldest son Yasin are caught and humiliated by the British soldiers. They are just representations of the Egyptian people. The implication is that the nation is represented at every stage of the action. Egypt is humiliated by Britain and is destined to suffer under the British colonization. In symbolic terms, Egypt is governed by forces of nature, heredity, and environment just like a man. The geographic location of Egypt and its natural resources has ever made it subject to attacks from different invaders and occupiers. So, Egypt, just like man, does not have free will. It is just a protectorate. Historically, Egypt was declared a British protectorate in 1882 (Sicker, 2001, p. 101). So, the humiliation of Al-Sayyid Ahmad, Yasin, and other Egyptians signifies the humiliation of the nation.

According to Sollars and Jennings (2008, p. 121), Mahfouz extends his pessimistic view about Egypt in Cairo Trilogy. In The Palace of Desire and The Sugar Street, the second and third volumes in the trilogy, "Egypt is not able to be an independent country". There is a pragmatism that purposefully hinders ebullience to the brief moments of revolutionary progress. Even in the Sugar Street, the third volume of the Saga, the waves of British colonial oppression continue preventing any hope for the rebirth of the nation. Just like Cairo and Egypt, the people in the Palace Walk are in constant states of negation, with realism. The life of Yasin, the eldest son, for instance, is a good example of this claim. Much of his psychological pain and suffering are due to his mother. His father divorced his mother years ago because she refused to be just a property to Al-Sayyid Ahmad. She did not like the idea that she can be enslaved by her husband. She refuses to be the property of her male guardian. She lives as a divorced woman in a society where divorced women were looked down upon society. Furthermore, her son is taken away from her. So, she herself was a victim of the external forces of the society. Her lifestyle afterward and her so many unequal marriages humiliated Yasin. Like this, Mahfouz illustrates to readers staidness in plotlines, as imitating the intrinsic social process in contemporaneous Egypt.

The life of Yasin can be compared to the life of prostitutes who occupy a great space in the novel. It seems that Mahfouz, in spite of his denials, follows the tradition of Emile Zola who was also concerned with prostitutes in his novels. Zola's Nana published in 1880 describes the career of a French prostitute. In Palace Walk, prostitutes are described as a necessary part of the economy of desire (Mondal, 2003). For biological and heredity reasons, however, they are determined to suffer. Through the character of Jalila, Mahfouz gives an example of a saintly woman which was a stereotypical image of the prostitute during this period. Grace $(2004$, p. 22$)$ indicates that prostitutes, like wives, were determined to be caught in the web of patriarchal exploitation. Prostitutes suffer because they only because they were born as women. They suffer just like all other women in society. So, it is biological considerations that determine their fate. Likewise, El-Saadawi (1997) argues that life within a male guardian was just hell for women at this time in Egypt. However, she insists that Mahfouz is just an objective observer of the woman's life, either as a "pure mother" or a prostitute and mistress" at this period. She explains that Mahfouz is more concerned with the depiction of the female social condition than stressing the tragedy of the woman at this time. This is again a contextualization of social realism where the writer is an objective observer of social phenomena around him.

It is through Jalila we see that religious and traditional conventions of the society that shunt prostitutes to the margins of the society. Although she rejects the religious stereotypes assigned to her, nothing changes. This is a belief that in spite of man's efforts to progress, he is destined to fail in flat-lining. Although Jalila has so many lovers and her sexuality make her vital to men, she is not respected by society and none of her men think of her as a wife. Jalila can expose the men for their hypocritical treatment of the women, but she is still looked upon as a mere body. She is just a body over which he has control and to which he always has access: "No woman was anything more than a body to him" (Naguib Mahfouz, Palace Walk, 2001, 99).

The relationship between Al-Sayyaid Ahmad in Palace Walk with prostitutes like Jalila and Zubayda is very similar in many ways to the relationship between Soames and Irene in The Man of Property. Al-Sayyid Ahmad cannot find sexual pleasure or fulfilment with his wife Amina who is completely desexualized because she is a 
respected woman. So, he meets his sexual needs with prostitutes who are very important to him. For Soames, Irene is just a beautiful body. After marriage, Irene discovers that Soames is sexually repellent. When she asks him to sleep in separate bedrooms, he rapes her. This leads us to an important feature in both Palace Walk and The Man of Property. It can be claimed that sexuality is a central feature of the two plots which is also treated in an explicit way. Although sexual frankness was unfamiliar during Mahfouz' age, he offers a detailed depiction of sexual obsessions of father and sons as well as the sinfulness of sexual impulse. Mondal (2003, p. 6) argues that the novels of Cairo Trilogy dwell repeatedly and at length on the female body as an object of sexual desire and almost all male sexual desires, in terms of possessing such sexualized bodies, are satisfied. Mahfouz is explicit in describing the women's bodies even when they are in black garments. Similarly, Galsworthy, unlike Victorian writers, treats sex in a frank, blunt, matter-of-fact manner. Frankness about sexuality is one of the characteristics of Zola's writings on literary scientific logic. Woods (1999) agrees that such novelists sharing Zola's model tended to treat sexual matters in an explicit way where the sexual content is presented frankly and freely. The rationale is these writers are concerned with the truths as they observe it, not as they like or wish it.

\section{Discussion}

Women and gender roles are among the main themes in both The Man of Property and Palace Walk. Both John Galsworthy and Naguib Mahfouz dwell on the detailed depiction of women's life during the World War 1 period where women were denied many of their rights. In the two texts, there is the image of a husband who has the belief that women are considered objects of property. In the two novels, there is a close relation between the concept and laws of property on one hand and the perception of marriage on the other. In The Man of Property, Soames thinks that he is the legal owner of Irene, his wife who, according to his beliefs, does not the right to resist him or be wrested from him. He never respected her demand for separate rooms. When she resists him, he rapes her. This represents the climax of the narrative. Soames rapes Irene because she does not have any sexual attraction to him. Soames' act reflects the idea that he sees her as an object which he owns. He believes that his sexual abuse of her and her body does not violate rules in any way. He does not respect her privacy since her body is already owned by him. Soames does not consider his act is an invasion of the inner space of his wife and a violation of the entire female body. In the rape scene, Galsworthy describes Irene's body as vulnerable, violable, penetrable, and wounded. As the title of the novel itself suggests, Galsworthy considers Soames' sexual abuse of Irene as a brutal invasion of female sexual property. Galsworthy reflects his belief that there is a close relationship between rape culture and property concepts and laws. They indicate that adherents of rape culture see women and their bodies as a property that they own where they give themselves the right to the exclusive ownership and control over their own bodies. So, both Irene and Soames represent ideas. They are just types. They are symbols of the relationship between and women of the age. This objectivity in introducing social reality is one of the characteristics that best expressed in terms of sociopragmatic theory.

Galsworthy also hints that rape was very frequent at the age. He discusses the issue in an objective way. However, it is like a cry against the injustice of the society towards the woman. Rape was not considered a crime at that time. Soames read in the Times about rape accidents with other sorts of crimes and accidents. The irony is that Soames was reading about rape and how surprising for him was the number of rapes while thinking of his wife's tears and stained face. His mind could not forget "the memory of Irene's tear-stained face and the sounds of her broken heart" (Galsworthy, 1906, p. 484). He could not make any link between rape crimes he is reading about and his rape of his wife. This is simply because he thinks she is one of his possessions and he has the right to enjoy her beautiful body whenever he likes regardless of her opinion or wish. For him, Irene is just a beautiful body he is paying money for to get pleasure. He just thinks that lives in luxury and all her materialistic needs, so she should not be upset. He does not respect her feeling that she lacks definitely and utterly any sexual attraction towards him. Irene, like many girls of her age, was not prepared to deal with the realities of sex. He adds that marriage, for a woman of her mentality and independent thinking, did not necessarily equate with the right to sexual relationship. The novels also deal with the problem of female sexuality. Like other typical virgins of her age, Irene was also quite unprepared to cope with the realities of sex. Moreover, to an independent mind like Irene's, marriage posed similar challenges.

In Palace Walk, women are victims of the same factors: inequality and unjust marriage/divorce customs. They are humiliated by the male patriarch who is represented in the character of Al-Sayyid Ahmad. He is a prosperous merchant who is successful in attracting customers as well as women. So, he considers women as a commodity which he can buy and sell at any time. He thinks that his money enables him to buy any woman. While sitting in his shop once, Jalila, who is called the Sultana comes to get some stuff. He is very kind and generous with her and gives her the stuff for free. However, they both (Al-Sayyid Ahmad and Sultana) realize that this gift is for his pleasure. Jamil Hamzawi, the shop assistant, is not pleased with the so many items she took for free and asks 
how this sum can be accounted for. Al-Sayyid Ahmad replies that Goods destroyed by love. The implication here is that the setting is a shop where Al-Sayyid Ahmad is very clever in dealing with his clients. He is a very successful merchant. So, he thinks that the female body is just a commodity that he can buy and even sell.

Mahfouz's portrayal of women and gender relations are the main reasons behind the immense popularity and large amount of attention that Palace Walk has attracted over the years. In The Social Impact of the Novel: A Reference Guide, Johnson and Johnson (2002, p. 4) argue that the treatment of women is the dominating theme in the novel. They maintain "no other problem so permeates Palace Walk, the first novel about a Cairo family, as the Muslim view and treatment of women and the tyranny of husbands: the ability of husbands to take more than one wife, to take mistresses, to beat and mutilate their wives, to throw them out at will where they become pariahs, to forbid them from ever leaving the house, and to control their children's marriages". Numerous, yet contradicting, interpretations have been developed in relation to the position of woman and how she was perceived by Naguib Mahfouz. Many critics insist that Mahfouz's treatment and consideration of gender are progressive indicating that he adopted an anti-patriarchal stance. On the other hand, others argue that Mahfouz represented a passive image of the woman either as a wife or even a prostitute stressing that women's rights are not assured in the novel.

In Palace Walk, Naguib Mahfouz reflects the dominance of men and the submissiveness of women in the Egyptian society during and after World War 1. It was, according to (El-Guindi, 2005, p. 65), the most brutal period of internal patriarchy in the history of Egyptian woman. At that time, women lived in what can be described seclusion. Women were just kept at home. Three were no employment programs for women and schooling opportunities were very limited and were not free. Families had to pay for the education of their girls. One aspect of seclusion was veiling or hijab, a Muslim tradition. Women were asked to wear the hijab so they cannot be seen or identified by others. A woman was only allowed to uncover her face for family members. The novel portrays women as confined to the house where they are asked to meet all the needs of men who are, in turn, free to live their lives the way they like. Mahfouz gave a true and realistic image of the wife during this period in the character of Amina. She learned by customs and traditions that her only role as a wife is to serve her husband and meet his needs. She has no right to question him or object to any of his decisions.

Mahfouz hints that Amina had nothing but to submit to her husband's will. She is always under the pressure that he can divorce her. She realizes that he married her after divorcing his first wife (Yasin's mother) and her own father had many wives. That is why, she has never objected to any of his conduct or misbehaviors. It was the rule that transferred orally from one generation to another indicating that wives have to accept their husbands as they are and agree with him whatever he was saying. In one of the dialogues between Al-Sayyid Ahmad and his wife Amina, he is telling her about the death of the Sultan and reflects his opinion about the Sultan's son position in rejecting to ascend to the throne as long as Egypt is colonized by Britain. Amina has nothing to say but to agree with her husband. She cannot form an opinion herself. This is mainly because she is secluded from the society in which she lives. It is also due to the fact that she cannot oppose her husband in any way.

In spite of her obedience, however, she is thrown away for just going out once to visit Al-Hussain Mosque. The case of wives extends to prostitutes in Palace Walk. They are also dominated and humiliated by male patriarchs. Although prostitutes are represented as having a strong sexual power by which they dominate the male society, they are still marginalized since their power is very limited in scope. Worth noting, the patriarch discourse, and acts of Al-Sayyid Ahmad extends to every female character in his family. It is not only his wives who are mistreated by him, his daughters as well suffer his dominance. That is why, they are eager to marry so that they will be free from their father's tyranny. The irony is that they will move from one seclusion to another. It was an entire social system where Al-Sayyid Ahmad is just a symbol.

In his description of women's problems and sufferings, Mahfouz considered objectivity and it seems that there is a sense of scientific detachment that characterizes the relation between Naguib Mahfouz and his characters. Mahfouz did not fight for women's rights. He did not also support women explicitly in their social and political struggle against the forces of society. That is why; he was blamed by many critics for not explicitly supporting woman's cause. El-Saadawi (2013) asserts that Mahfouz was never a revolutionary or a reformer. She is critical of the image of the Arab woman produced by men including Mahfouz. She stresses that Mahfouz did not defend women's rights in his texts. He was an objective observer who represented a reality. Mahfouz does not offer any resistance to the way women were treated in Cairo society. Critics also blamed Mahfouz for introducing the prostitutes as greedy women with disreputable functions. These arguments can be refuted in the sense that Mahfouz was concerned with society as a whole construct, not just individuals and the characters are just types. He did not also reflect his own perceptions explicitly. He was just concerned with reality and truth without instructing or teaching his readers. In this, he follows the principles of Leech's Speech Act Theory. In his book 
Naguib Mahfouz: The Novelist-Philosopher of Cairo, Milson (1998) asserts that characters in Mahfouz's (2001) Cairo Trilogy are just fictional types who are employed by the author to serve functional roles.

In her book Gender, Nation, and the Arabic Novel: Egypt 1892-2008, El-Sadda (2012, p. 77) criticizes Mahfouz for his representation of patriarchal practices and the oppression of women; however, she does not classify him as anti-feminist. She thus claims that gender relations in Palace Walk ad Cairo Trilogy reflect a realistic picture of the age in what she calls a "national allegory". This may agree in some way to Miriam Cooke's argument of Mahfouz's treatment of gender. Cooke (1994, p. 107) argues that Mahfouz could be considered a feminist writer because of his exploration of the shifting gender relations within Egyptian society during that period, and his incisive critique of masculinity within that shift, especially in the way he illuminates gender relations to be "grounded in asymmetric power". She adds that "to understand the significance of Mahfouz's female characters, we must strip away the sexist bias that has informed canonical readings and instead view his works through a feminist optic" $(1994,110)$. Cooke's argument supports the idea that Mahfouz did not favor the male dominance or that patriarch discourse of his hero. He was not also speaking in the name of God or Islam since these traditions do not represent Islam. He was just referring to a group of people who resist women's rights and defend male tyranny in any way. According to (Mernissi, 1987, p. ix) in her book Beyond the Veil: Male-Female Dynamics in Modern Muslim Society, "women's rights present problem for some modern Muslim men not necessarily because of the Quran or the tradition of the Prophet, both of which are subject to interpretation, nor the Islamic tradition, but simply because those rights conflict with the interests of a male elite".

\section{Conclusion}

This study analyzed the representation of women and gender roles in John Galsworthy's Forsyte Saga and Naguib Mahfouz's Cairo Trilogy. It attempted to answer the main research questions relating to the ways the two authors Naguib Mahfouz and John Galsworthy used to treat and represent women and gender roles in the selected texts. The two novels Galsworthy's The Man of Property and Mahfouz's Palace Walk can be claimed to be examples of social realism that best expressed through the speeches of the participants involved. Both Naguib Mahfouz and John Galsworthy tended their two novels to be a realistic portrayal of that given period in history. The two authors used societal orders and practices as vehicles for symbolic meanings to convey thematic significance. Through the voices of the male and female characters, we see that women are fixed to suffering and have a passive agency to male dominance and tyranny. We see also in the two texts how women are exploited for female beauty. Both John Galsworthy and Naguib Mahfouz adopt social realism in their treatment of gender and the representation of women in the two trilogies. The two authors assume the role of observers in revealing the societal unjust laws and customs concerning women's rights. It is also clear that sociopragmatic analysis has salience in evaluating gender relations. In this way, it can be suggested that contextual aspects of the texts including the social and political backgrounds are imperative and key elements for understanding the texts. This leads to the conclusion that sociopragmatic approaches can be usefully used for a better and deeper understanding of literary works.

\section{Acknowledgments}

I take this opportunity to thank Prince Sattam Bin Abdulaziz University in Saudi Arabia alongside its Scientific Deanship, for all technical support it has unstintingly provided towards the fulfillment of the current research project.

\section{References}

Al-Issa, A. S. (2003). Sociopragmatic Transfer in the Performance of Refusals by Jordanian EFL Learners: Evidence and Motivating Factors. Indiana University of Pennsylvania.

Austin, J. (1962). How to Do Things with Words. London: Clarendon Press.

Barakat, H. I. (1993). The Arab world: society, culture, and state. Berkeley: University of California Press.

Beeching, K., \& Woodfield, H. (2015). Researching Sociopragmatic Variability: Perspectives from Variational, Interlanguage and Contrastive Pragmatics. Palgrave Macmillan UK. https://doi.org/10.1057/9781137373953

Clark, L. M. G., \& Lewis, D. J. (1977). Rape: The Price of Coercive Sexuality. Women's Press.

Cooke, M. (1994). Men Constructed in the Mirror of Prostitution. In P. F. Murphy (Ed.), Fictions of Masculinity: Crossing Cultures Crossing Sexualities (pp. 96-120). New York: New York University.

Crow, B. A. (2000). Radical Feminism: A Documentary Reader. NYU Press.

Culpeper, J. (2011). Historical Sociopragmatics. John Benjamins Publishing Company. 
https://doi.org/10.1075/bct.31

Drinkwater, J. (1923). The Outline of Literature (Vol. 1). London: George Newnes.

Edwards, S. (2011). The Rise and Fall of the Forsytes from Neo-Victorian to Neo-Edwardian Marriage. In M.-L. \& C. Gutleben (Eds.), Neo-Victorian Families: Gender, Sexual and Cultural Politics (pp. 197-220). Amsterdam: Rodopi. https://doi.org/10.1163/9789401207249_009

El-Enany, R. (1993). Naguib Mahfouz: The Pursuit of Meaning. London, New York: Routledge.

El-Guindi, F. (2005). Gendered Resistance, Feminist Veiling, Islamic Feminism. The Ahfad Journal, 22(1), 5394.

El-Saadawi, N. (1997). The Nawal Al-Saadawi Reader. New York: St. Martin's Press.

El-Saadawi, N. (2013). Hans Ulrich Obrist in Conversation with Nawal Al-Sadawi. E-Flux Journal, 42.

El-Sadda, H. (2012). Gender, nation, and the Arabic novel: Egypt, 1892-2008. Edinburgh: Edinburgh University Press: Syracuse University Press.

El-Shall, M. H. (2006). Modern Interpretations of Gender in Naguib Mahfouz's Cairo Trilogy. University of Florida.

Frechet, A. (1982). John Galsworthy: A reassessment. London: Macmillan. https://doi.org/10.1007/978-1-349-05995-9

Ghīṭānī, J. (2012). The Cairo of Naguib Mahfouz. Cairo: American University in Cairo Press.

Gorsky, S. R. (1992). Femininity to feminism: Women and literature in the nineteenth century. Twayne.

Grace, D. (2004). The Woman in the Muslim Mask: Veiling and Identity in Postcolonial Literature. London: Pluto Press.

Hatif, H., \& Hatif, A. (2012). The Psychological and Moral Impact of Property in John Galsworthy's The Man of Property. College of Basic Education Journal, 80(19), 839-847.

Hubble, N. (2011). In the Twentieth Century, and the Heart of Civilisation: The London of the Forsytes. Literary London Journal: Interdisciplinary Studies in the Representation of London, 9(1).

Johnson, C. D., \& Johnson, V. E. (2002). The Social Impact of the Novel: A Reference Guide. Greenwood Publishing Group.

Khosrowpour, M. (2002). Issues \& Trends of Information Technology Management in Contemporary Organizations. Idea Group Publishing.

Kohlke, M.-L., \& Gutleben, C. (2011). Neo-Victorian Families: Gender, Sexual and Cultural Politics. Amsterdam: Rodopi. https://doi.org/10.1163/9789401207249

Langbauer, L. (1999). Novels of Everyday Life: The Series in English Fiction. Cornell University Press.

Leech, G. (1983). Principles of Pragmatics. London: Longman.

Lutzky, U. (2012). Discourse Markers in Early Modern English. John Benjamins Publishing Company. https://doi.org/10.1075/pbns.227

Mernissi, F. (1987). Beyond the Veil: Male-Female Dynamics in Modern Muslim Society. Indiana University Press.

Milson, M. (1998). Naguib Mahfouz: The Novelist-Philosopher of Cairo. New York: St Martin's Press.

Mondal, A. A. (2003). Nationalism and post-colonial identity: culture and ideology in India and Egypt. London: Routledge Curzon. https://doi.org/10.4324/9780203498989

Moosa, M. (1994). The early novels of Naguib Mahfouz: images of modern Egypt. Gainesville, Fla.: University Press of Florida.

Riley, P. (2007). Language, Culture and Identity: An Ethnolinguistic Perspective. Bloomsbury Publishing.

Santesso, E. M., \& McClung, J. (2017). Islam and Postcolonial Discourse: Purity and Hybridity. Taylor \& Francis. https://doi.org/10.4324/9781315589923

Searle, J. (1969). Speech Acts: An Essay in the Philosophy of Language. Cambridge: Cambridge University Press. https://doi.org/10.1017/CBO9781139173438

Sicker, M. (2001). The Middle East in the twentieth century. Westport, Conn.: Praeger. 
Sollars, M., \& Jennings, A. L. (2008). The Facts on File Companion to the World Novel: 1900 to the Present. New York: Infobase Publishing.

Watson, E. (1973). The English and American Estimates of Galsworthy as a Novelist. $\mathrm{PhD} \mathrm{PhD}$ thesis, University of Arizona.

Woods, S. (1999). War of the Words: The Battle over the New Realism (Vol. 11). Fairmont State College Occasional Papers.

\section{Copyrights}

Copyright for this article is retained by the author, with first publication rights granted to the journal.

This is an open-access article distributed under the terms and conditions of the Creative Commons Attribution license (http://creativecommons.org/licenses/by/4.0/). 